\title{
Changes in platelet vasopressin after smoking in relation to platelet function
}

\section{Masaya Urakami, Yukihisa Umeda, and Yoko Yamane}

Second Department of Internal Medicine, Kansai Medical University, Moriguchi City, Osaka 570-8507, Japan

(Received for publication February 15, 1999)

All correspondence should be addressed to Masaya Urakami.

Second Department of Internal Medicine, Kansai Medical University

10-15 Fumizono-cho, Moriguchi City, Osaka 570-8507, Japan (Fax) 06-6998-6178 (Phone) 06-6992-1001

Key words: nicotine, platelet, vasopressin, receptor, aggregation, desensitization

\begin{abstract}
Summary
We examined the effects of smoking on plasma and platelet arginine vasopressin (AVP) levels, platelet aggregation with AVP, and AVP binding to platelets in normal subjects. Plasma and platelet AVP levels increased to the peak level at 5 to $10 \mathrm{~min}$ after the start of smoking, and decreased thereafter in parallel with plasma nicotine levels. A good correlation was found between plasma nicotine levels and plasma AVP levels, and also between plasma and platelet AVP levels. These results suggest that platelets rapidly take up endogenously released AVP from plasma. We also observed a decreased platelet aggregation with AVP ex vivo when the plasma and platelet AVP levels were elevated in vivo after somking. Binding experiments of washed platelets did not demonstrate any change in receptor number or affinity before and after smoking. These findings indicate that endogenously released AVP taken up by platelets desensitizes platelets to AVP without loss of AVP receptor number or modification of receptor affinity for AVP.
\end{abstract}

\section{Introduction}

The neurohypophyseal hormone arginine vasopressin (AVP) has multiple actions, including antidiuresis in the kidney, contraction of smooth muscle cells, stimulation of liver glycogenolysis, modulation of adrenocorticotropic hormone release from the pituitary. These actions of AVP are mediated through specific $G$ protein-coupled receptors. AVP receptors have been classified into at least three subtypes, Vla (vascular hepatic), V1b (anterior pituitary), and V2 (kidney) AVP receptors [1]. In addition to many other actions, AVP has been shown to induce shape changes and aggregation of human platelets $[2,3]$. We and others $[3,4,5,6]$ have described the characteristics of specific receptor belonging to the $\mathrm{V} 1 \mathrm{a}$ vascular subtype on intact human platelets. About $90 \%$ of the circulating immunoreactive AVP in normal humans is found in platelets $[3,7,8,9]$, and is associated with the membrane component of platelets [10]. However, it remains controversial whether platelets take up AVP from the plasma and discharge it with the change in plasma AVP levels. Provided that platelets take up the endogenously released AVP, it would be of interest to know its pathophysiological significance. Although cigarette smok. ing is known to stimulate the release of AVP, it remains controversial whether or not the smoking-induced increase in plasma AVP is caused by nicotine stimulation.

In the present study, we estimated plasma nicotine levels and AVP levels in platelet-free plasma (PFP) and platelets after stimulation of endogenous AVP release by acute cigarette smoking in healthy subjects. We also performed a platelet aggregation study with AVP, as well as binding assay of AVP to intact platelets. 


\section{Subjects}

Twelve men (mean age, $28.8 \pm 0.9$ years) from the medical school staffs, who were in good general health and had not taken any medications for at least 10 days, participated in this study. They were all habitual smok ers, and smoked an average of 20 cigarettes per day. They gave informed consent before the study and were abstained from food, water and cigarettes overnight prior to the study.

\section{Methods}

Venous blood samples were obtained from the antecubital vein using an indwelling vein needle to measure the plasma nicotine levels and AVP levels in the PFP and platelets, and to carry out the aggregation study and the AVP binding assay following $30 \mathrm{~min}$ rest in the sitting position. After baseline blood samples was obtained, the subjects smoked one commercial filter cigarette (containing $2.2 \mathrm{mg}$ nicotine per cigarette) with deep inhalation over a period of $5 \mathrm{~min}$. Blood samples were obtained at 5, 10 and 30 minutes after the start of smoking. Plasma nicotine levels and AVP levels in PFP and platelets were estimated. Platelet aggregation studies were performed at $0,5,10$ and $30 \mathrm{~min}$, and binding assays were carried out at 0 and $30 \mathrm{~min}$.

\section{Radioimunoassay of PFP and platelet AVP}

For radioimmunoassay of the AVP, $10 \mathrm{ml}$ of venous blood was taken into a plastic syringe containing $50 \mathrm{ml}$ heparin and centrifuged at $140 \mathrm{~g}$ for $10 \mathrm{~min}$ at $25^{\circ} \mathrm{C}$ to obtain platelet-rich plasma (PRP). Then, $1 \mathrm{ml}$ of PRP was centrifuged at $25000 \mathrm{~g}$ for $15 \mathrm{~min}$ at $4^{\circ} \mathrm{C}$ tó obtain platelets and platelet-free-plasma (PFP). The platelet count in the PRP was $5.21 \pm 0.41 \times 10^{5} / \mathrm{ml}$, which was less than $5 \times 10^{3} / \mathrm{ml}$ in the PFP. The platelet pellet from $1 \mathrm{ml}$ of PRP was suspended in isotonic saline containing $0.1 \%$ bovine serum albumin (BSA; Sigma Chemical Co., St. Louis, Mo, USA). PFP and platelet AVP levels were measured by specific radioimmunoassay after extraction by the acetone-petroleum ether method as reported previously [11]. Highly specific antibody to AVP was a kind gift from Dr. T. Saito (Jichi Medical College, Tochigi, Japan). It did not cross-react with dDAVP and oxytocin, but $4.2 \%$ cross-reactivity was observed with lysine vasopressin. The intra-assay and inter-assay coefficients of variation were $6.0 \%$ and $7.4 \%$, respectively, with a detection limit of $0.7 \mathrm{fmol} / \mathrm{ml}$. The platelet AVP levels were expressed as AVP from $1 \mathrm{ml}$ of $\mathrm{PRP}$, in which the platelet number was corrected to $5 \times 10^{4} / \mathrm{ml}$

\section{Measurement of plasma nicotine levels}

Separate samples of PRP were centrifuged at $1400 \mathrm{~g}$ to obtain supernatant for measurement of the plasma nicotine levels and plasma osmolalities.

The plasma nicotine levels were determined by the FTD-gas chromatographic technique according to Feyerabent and Russel [12] after microextraction (using $100 \mathrm{ml}$ plasma) with isopropyl ether. A Hitachi gas chromatograph (Model 153, Hitachi Co., Tokyo, Japan) equipped with an FTD detector was used. The glass columns $(2 \mathrm{~m}$ $\times 3 \mathrm{~m}$ id) were packed with $80-100$ mesh chromosorb W-AW, coated with $10 \%$ Apiezon L and $10 \% \mathrm{KOH}$. The flow rate of carrier gas (helium) was $50 \mathrm{ml} / \mathrm{min}$, and the column temperature, injection port temperature and detector temperature were $190^{\circ} \mathrm{C}, 300^{\circ} \mathrm{C}$, and $300^{\circ} \mathrm{C}$, respectively. With this method, the calibration curve was linear over a working range of 20 to $100 \mathrm{ng} / \mathrm{ml}$. The recovery of added nicotine at between 2 to $10 \mathrm{ng}$ to 100 $\mathrm{ml}$ of plasma was about $100 \%$, and the intra-assay coefficients of variation were $12.9,3.4$ and $4.2 \%$. respectively, when 2,5 and $10 \mathrm{ng}$ of nicotien was added.

\section{Platelet AVP bindig assays}

Binding assays were performed as reported previously [3], with slight modifications. Briefly, $17 \mathrm{ml}$ of whole blood was collected into a plastic syringe containing $3 \mathrm{ml}$ of citrate-phosphate-dextrose solution, and immediately transferred to a plastic tube containing EDTA-2Na $(2 \mathrm{mg} / \mathrm{ml})$. The blood was centrifuged at $140 \mathrm{~g}$ for $10 \mathrm{~min}$ at $25^{\circ} \mathrm{C}$ to separate the PRP was washed with Tris. $\mathrm{HCl}$ Buffer-A (Tris- $\mathrm{HCl} 50 \mathrm{mM}, \mathrm{NaCl} 138 \mathrm{mM}$, EDTA-2Na $5 \mathrm{mM}$, glucose $2 \mathrm{mg} / \mathrm{ml}$, ph 7.4 ) and centrifuged at $1500 \mathrm{~g}$ for $10 \mathrm{~min}$ at $4^{\circ} \mathrm{C}$. The platelet pellet was washed twice with the same buffer and resuspended in Tris- $\mathrm{HCl}$ Buffer-B (Tris- $\mathrm{HCl} 50 \mathrm{mM}, \mathrm{NaCl} 138 \mathrm{mM}, \mathrm{MgCl}_{2} 10 \mathrm{mM}$, glucose $2 \mathrm{mg} / \mathrm{ml}, \mathrm{pH} 7.4)$, and adjusted to $10^{6}$ platelets $/ \mathrm{ml}$. For the binding assay, $150 \mathrm{ml}$ of platelet suspension, $1 \mathrm{nM}$ of $\left[{ }^{3} \mathrm{H}\right]$ AVP (New England Nuclear, Boston, MA, USA) and $20 \mathrm{ml}$ of various concentrations of un labelled AVP (Grade VI, Sigma Chemical Co., St. Louis, 
Table 1. PFP and platelet AVP levels, plasma nicotine levels and maximal percentage aggregation with AVP before and after smoking.

\begin{tabular}{|c|c|c|c|c|}
\hline & & Before & Peak & $30 \mathrm{~min}$ after \\
\hline $\begin{array}{l}\text { Plasma nicotine } \\
\text { (ng/ml) }\end{array}$ & $\begin{array}{l}\text { A } \\
\text { B }\end{array}$ & $\begin{array}{l}4.9 \pm 1.7 \\
4.5 \pm 3.4\end{array}$ & $\begin{array}{l}24.7 \pm 4.2 * * * \\
79.9 \pm 23.9 *\end{array}$ & $\begin{array}{l}11.6 \pm 3.0 * \\
23.9 \pm 4.9\end{array}$ \\
\hline $\begin{array}{l}\text { PFP AVP } \\
(f \mathrm{~mol} / \mathrm{ml})\end{array}$ & $\begin{array}{l}\text { A } \\
\text { B }\end{array}$ & $\begin{array}{l}2.8 \pm 0.5 \\
8.4 \pm 1.3\end{array}$ & $\begin{array}{r}34.8 \pm 12.6 * \\
107.8 \pm 30.3 *\end{array}$ & $\begin{array}{r}7.0 \pm 1.6 \\
27.6 \pm 2.8\end{array}$ \\
\hline $\begin{array}{l}\text { Platelet AVP } \\
\text { (f mol/m1) }\end{array}$ & $\begin{array}{l}\text { A } \\
\text { B }\end{array}$ & $\begin{array}{l}14.9 \pm 2.2 \\
23.6 \pm 2.5\end{array}$ & $\begin{array}{c}26.1 \pm 5.4 * \\
135.1 \pm 22.3 *\end{array}$ & $\begin{array}{l}20.3 \pm 2.9 \\
49.3 \pm 6.8\end{array}$ \\
\hline Maximal aggregatio & $(\%)$ & & & \\
\hline with $500 \mathrm{nM}$ AVP & $\begin{array}{l}\mathrm{A} \\
\mathrm{B}\end{array}$ & $\begin{array}{l}32.4 \pm 7.1 \\
50.3 \pm 14.7\end{array}$ & $\begin{array}{r}22.8 \pm 7.0 * \\
4.0 \pm 1.5 *\end{array}$ & $\begin{array}{l}32.8 \pm 8.3 \\
38.3 \pm 12.3\end{array}$ \\
\hline with 250 nM AVP & $\begin{array}{l}\text { A } \\
\text { B }\end{array}$ & $\begin{array}{l}33.4 \pm 8.0 \\
52.3 \pm 15.7\end{array}$ & $\begin{array}{r}21.3 \pm 6.1 * \\
4.0 \pm 1.0 *\end{array}$ & $\begin{array}{l}29.9 \pm 7.6 \\
32.0 \pm 9.7\end{array}$ \\
\hline with $100 \mathrm{nM}$ AVP & $\begin{array}{l}\text { A } \\
\text { B }\end{array}$ & $\begin{array}{l}33.4 \pm 7.7 \\
50.3 \pm 14.5\end{array}$ & $\begin{array}{r}22.8 \pm 6.9 * \\
4.3 \pm 0.9 *\end{array}$ & $\begin{array}{l}31.6 \pm 9.0 \\
33.7 \pm 10.4\end{array}$ \\
\hline with $50 \mathrm{nM}$ AVP & $\begin{array}{l}\mathrm{A} \\
\mathrm{B}\end{array}$ & $\begin{array}{l}29.6 \pm 7.0 \\
45.0 \pm 13.1\end{array}$ & $\begin{array}{r}20.4 \pm 5.9 * \\
3.7 \pm 1.2 *\end{array}$ & $\begin{array}{l}28.6 \pm 7.6 \\
29.0 \pm 8.5\end{array}$ \\
\hline Maximal aggregation & (\% o & of baseline) & & \\
\hline with $500 \mathrm{nM}$ AVP & $\begin{array}{l}\mathrm{A} \\
\mathrm{B}\end{array}$ & $\begin{array}{l}100 \\
100\end{array}$ & $\begin{array}{r}65.5 \pm 12.1 \text { ** } \\
8.2 \pm 1.7 \text { *** }\end{array}$ & $\begin{array}{l}94.7 \pm 10.4 \\
74.2 \pm 5.9 * *\end{array}$ \\
\hline with 250 nM AVP & $\begin{array}{l}\text { A } \\
\text { B }\end{array}$ & $\begin{array}{l}100 \\
100\end{array}$ & $\begin{array}{r}62.9 \pm 11.0 * * \\
9.2 \pm 3.5 * * *\end{array}$ & $\begin{array}{l}89.0 \pm 8.6 \\
61.5 \pm 4.0 * *\end{array}$ \\
\hline with $100 \mathrm{nM}$ AVP & $\begin{array}{l}\text { A } \\
\text { B }\end{array}$ & $\begin{array}{r}-100 \\
100\end{array}$ & $\begin{array}{l}64.0 \pm 11.0 * * \\
10.6 \pm 3.9 * * *\end{array}$ & $\begin{array}{l}90.6 \pm 9.2 \\
65.4 \pm 4.0 * *\end{array}$ \\
\hline With $50 \mathrm{nM}$ AVP & $\begin{array}{l}\text { A } \\
\text { B }\end{array}$ & $\begin{array}{l}100 \\
100\end{array}$ & $\begin{array}{r}65.6 \pm 11.6 \text { ** } \\
9.7 \pm 3.5 \text { *** }\end{array}$ & $\begin{array}{l}90.6 \pm 6.7 \\
64.1 \pm 0.6 * *\end{array}$ \\
\hline
\end{tabular}

A: subjects without nausea $(n=9), B$ : subjects with nausea $(n=3)$

$※ ※ ※ p<0.001, ※ ※ p<0.01, ※ p<0.05$ compared with the baseline level 
MO, USA), and $12.5 \mathrm{ml}$ of $4 \% \mathrm{BSA}$, adjusted a final volume to $250 \mathrm{ml}$ with Tris- $\mathrm{HCl}$ buffer-B, were incubated at $25^{\circ} \mathrm{C}$ for $180 \mathrm{~min}$ in duplicate. After incubation, the reaction was stopped by adding $4 \mathrm{ml}$ of ice-cold buffer-B, and the samples were rapidly filtered using Whatman $\mathrm{GF} / \mathrm{C}$ filter to separate free from bound $\left[{ }^{3} \mathrm{H}\right]$ AVP. After the filters had been rinsed twice with $4 \mathrm{ml}$ of the buffer and dried, the radioactivity was counted in a Packard liquid scintillation counter (United Technologies Packard, IL, USA). The specific binding was defined as the difference between the total and non-specific binding. The nonspecific binding was defined as the radioactivity bound to the platelets in the presence of $2 \mathrm{mM}$ of unlabelled AVP. Scatchard analysis of competition curves was employed to estimate the receptor number and affinity, and the slopes and intercepts were calculated by the method of least squares.

\section{Platelet aggregation studies}

Platelet aggregation studies were carried out by the turbidometric methods of Born [6] using an NKK Hematracer I (Niko Bioscience, Tokyo, Japan) which was calibrated with PRP and PFP to 0 and 100\% light transmission, respectively. Employing $200 \mathrm{ml}$ of PRP from heparinized blood, which was adjusted to contain $4 \times 10^{5}$ platelets/ml, the platelet aggregation was recorded as the increase in light transmission occurring after the addition of AVP at $37^{\circ} \mathrm{C}$. The maximum increase in light transmittance obtained within $5 \mathrm{~min}$ after the addition of AVP was defined as the maximal percentage aggregation.

The effects of preincubation with nicotine on the AVP. induced aggregation of platelets in vitro were studied. The final concentration of nicotine added to the PRP was $100 \mathrm{ng} / \mathrm{ml}$, which was the highest level to be reached in vivo after somking. Following incubation with nicotine for $20 \mathrm{~min}$ at $25^{\circ} \mathrm{C}$ and then for $10 \mathrm{~min}$ at $37^{\circ} \mathrm{C}$, aggregation studies with fixed 4 concentrations $(500,250,100$ and $50 \mathrm{nM})$ of AVP were performed. The effects of nicotine on the AVP binding characteristics were also ex. amined. Binding experiments were reperformed after overnight incubation with $100 \mathrm{ng} / \mathrm{ml}$ of nicotine.

Statistical analysis. All values are expressed as the mean \pm SEM, and analyzed by two-way analysis of variance followed by Scheffe-type multiple comparison. Correlation coefficients were calculated by the least squares method.

\section{Results}

The subjects were divided into 2 subgroups according to the presence ( 3 subjects) or absence (9 subjects) of nausea during the experiments, since nausea is an important stimulating factor of AVP release.

Plasma nicotine levels increased to the peak level at 5 to $10 \mathrm{~min}$ after the beginning of smoking, and decreased thereafter in all subjects (Table. 1). However, there was a wide variation in the peak nicotine levels after smoking (4.1 to $125.2 \mathrm{ng} / \mathrm{ml}$ ), probably due to the technique of inhaling. Subjects with nausea achieved higher peak plasma nicotine levels after smoking than those without nausea $(79.9 \pm 23.9 \mathrm{ng} / \mathrm{ml}$ and $24.7 \pm 4.2 \mathrm{ng} / \mathrm{ml} \mathrm{re}$ spectively). The PFP and platelet AVP levels increased to the peak level at 5 to $10 \mathrm{~min}$ after the beginning of smoking, and decreased in parallel with plasma nicotine level. The subjects with nausea achieved much higher peak levels of PFP and platelet AVP than those without nausea (PFP-AVP; $107.8 \pm 30.3 \mathrm{f} \mathrm{mol} / \mathrm{ml}$ vs. $34.8 \pm$ $12.6 \mathrm{f} \mathrm{mol} / \mathrm{ml}$, platelet AVP; $135.1 \pm 22.3 \mathrm{f} \mathrm{mol} / \mathrm{ml}$ vs. $26.1 \pm 5.6 \mathrm{f} \mathrm{mol} / \mathrm{ml}$, respectively).

A significant correlation was found between plasma nicotine levels and PFP.AVP levels determined in the subjects without nausea $(r=0.72, p<0.001)$ (Fig. 1). However, PFP.AVP levels did not change in those with plasma nicotine level less than $18 \mathrm{ng} / \mathrm{ml}$. A significant correlation was observed between PFP.AVP levels and platelet AVP levels determined before and after smoking in all cases $(r=0.85, p<0.001)$ (Fig. 2). No subjects had significant change in plasma osmolality before and after smoking.

In contrast to an increase in PFP and platelet AVP levels, the maximal percentage aggregation with fixed 4 concentrations of AVP $(500 \mathrm{nM}, 250 \mathrm{nM}, 100 \mathrm{nM}$ and $50 \mathrm{nM}$ ofAVP) was significantly decreased at 5 to 10 min after smoking but recovered at $30 \mathrm{~min}$ in both groups. As maximal percentage aggregation with AVP showed wide variation before smoking, we expressed the maximal percentage aggregation as a percent of the presmoking value. Reduced platelet aggregation with AVP was observed more prominent in the subjects with nausea.

A significant inverse correlation was found between 


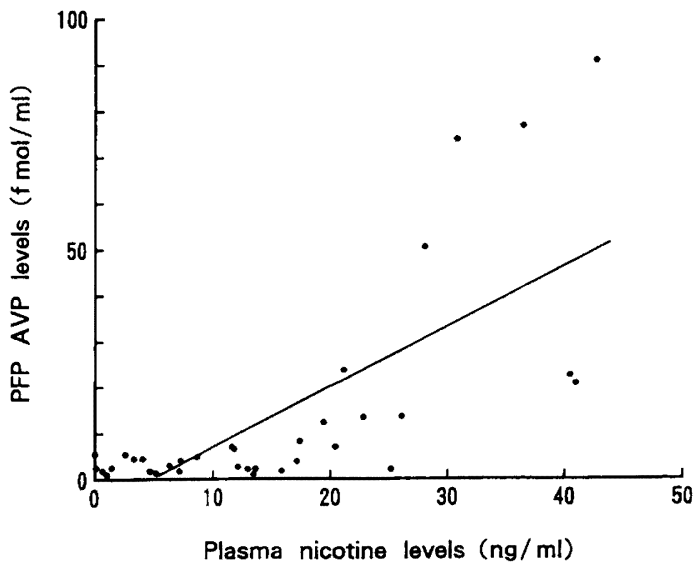

Fig. 1 Correlation between plasma nicotine levels and PFP AVP levels determined before and after smoking in the subjects without nausea. $\mathrm{Y}=-5.80+1.31 \mathrm{X} \quad \mathrm{r}=0.72, \mathrm{p}<0.001$

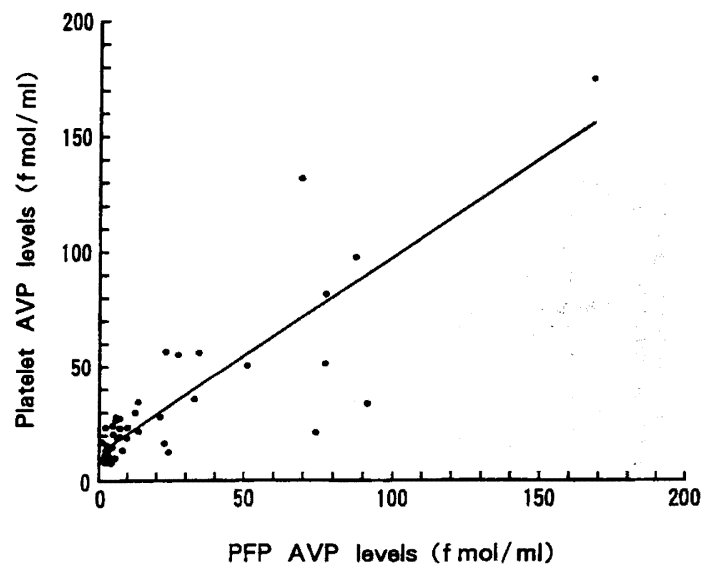

Fig. 2 Correlation between PFP AVP levels and platelet AVP levels determined before and after smoking in all cases. $\mathrm{Y}=12.79+0.82 \mathrm{X} \quad \mathrm{r}=0.85, \mathrm{p}<0.001$

aggregation.

\section{Discussion}

Cigarette smoking is thought to stimulate the release of AVP and its carrier protein, neurophysin, by nicotine stimulation [14-17] or by other mechanism [18]. The increase in plasma AVP produced by cigarette smoking is highly variable, because blood nicotine levels after smoking vary according to the degree of inhaling [19].

However, the plasma nicotine level was not determined in most previous studies. In the present study, we measured plasma nicotine and AVP levels in PFP and platelets after smoking. PFP-AVP levels increased to the peak level at 5 to 10 min after the beginning of smoking and decreased in parallel with the plasma nicotine levels. However, PFP.AVP levels did not change at low increase of plasma nicotine levels (plasma nicotine $<18 \mathrm{ng} / \mathrm{ml}$ ). The results were compatible with the report of Gold. smith et al. [20] who indicated that a plasma nicotine level of $16 \mathrm{ng} / \mathrm{ml}$ administered through chewing gum did not stimulate AVP secretion. Although an increase in AVP levels after smoking may be due to some other mechanisms as reported by Rowe et al [18], our results clearly show that smoking with low grade increase in plasma nicotine levels dose not stimulate endogenous 
(a)

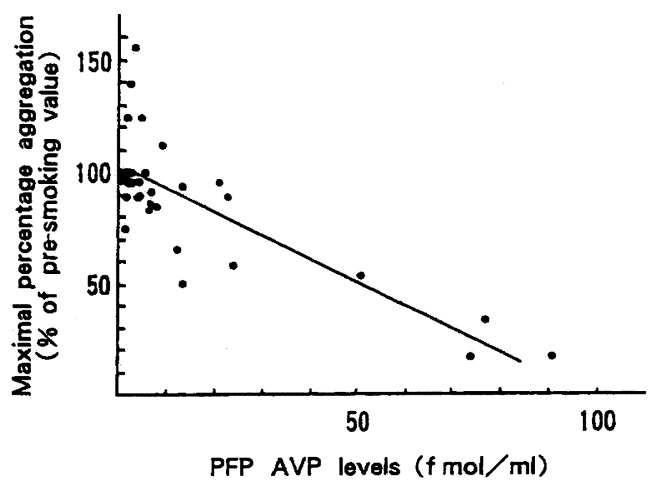

(b)

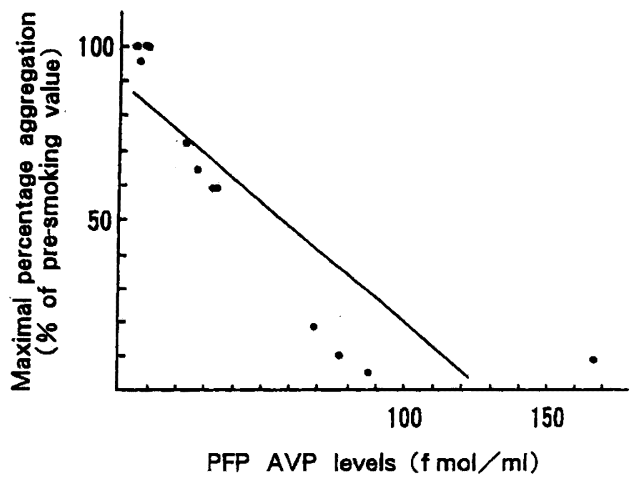

Fig. 3 Correlation between PFP AVP levels and the maximal percentage aggregation with $100 \mathrm{nM}$ AVP expressed as a percent of the pre-smoking value after smoking in the subjects without nausea (3-a) and in the subjects with nausea (3-b). $\mathrm{Y}=102.04-1.01 \mathrm{X} \quad \mathrm{r}=-0.80, \mathrm{p}<0.001 \quad(3-\mathrm{a})$ $\mathrm{Y}=89.46-0.69 \mathrm{X} \quad \mathrm{r}=-0.86, \mathrm{p}<0.001 \quad(3-\mathrm{b})$

(a)

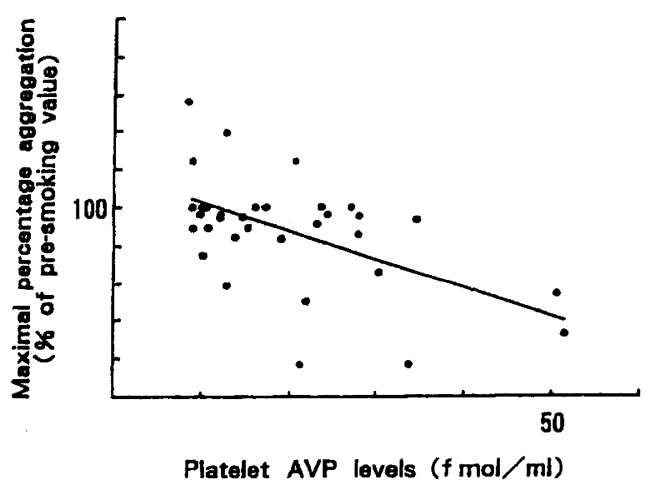

(b)

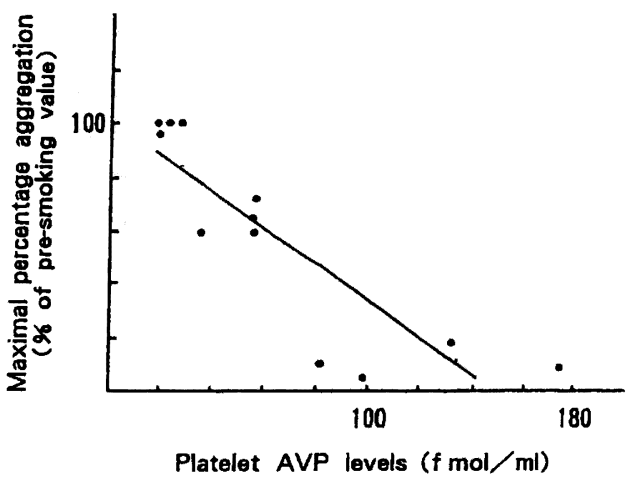

Fig. 4 Correlation between platelet AVP levels and the maximal percentage aggregation with $100 \mathrm{nM}$ AVP expressed as a percent of the pre-smoking value after smoking in the subjects without nausea (4-a) and in the subjects with nausea (4-b).

$$
\begin{array}{lll}
Y=115.91-1.44 X & r=-0.55, p<0.001 & (4-a) \\
Y=101.79-0.68 X & r=-0.87, p<0.001 & (4-b)
\end{array}
$$


release of AVP, but smoking with high grade increase in plasma nicotine levels stimulates AVP release in proportion to the plasma nicotine levels.

It remains controversial whether AVP is taken up by platelets when plasma AVP level is increased exogenous ly or endogenously in humans. Bichet et al. reported that changes in AVP levels by acute osmotic stimulation or suppression exerted little effect on platelet AVP, and small intravenous dose of AVP did not bind, but large dose of exogenous AVP could associate with the platelet fraction [9]. On the other hand, Nussay et al. found elevated platelet AVP levels after osmotic stimulation or intravenous infusion of a relatively small amount of AVP [8]. Preibisz et al. reported that human platelets could take up small amounts of AVP when the plasma AVP levels increased in response to tilt [7]. In a previous study, we failed to observe any increase in platelet AVP levels after osmotic stimulation, despite the increase in PFP AVP levels [3]. The present study clearly showed that platelets rapidly take up endogenously released AVP from the plasma, when plasma AVP levels become quite high level, but platelets discharge AVP thereafter. These data suggest that platelets may play a role in the rapid clearance of AVP from the circulation when the plasma AVP level becomes extremely high. Considering that platelets are in close contact with injured or atherosclerotic vascular wall, it is also possible that platelets provide a high concentration of AVP to the local vascular lesion.

AVP induces shape changes and aggregation of human platelets through V1a receptors, which are coupled to $G$ protein belonging to Gq11 family [21], and mediate phosphoinositide hydrolysis and elevation of the cytosolic free calcium [22]. We have shown that maximal percentage aggregation with AVP is directly related to the number of AVP receptors on platelets in healthy humans [3]. An enhanced platelet aggregation due to cigarette smoking or to nicotine has been reported $[23,24,25]$. On the other hand, reduced platelet sensitivity to AVP with increase in plasma AVP after smoking was found [28]. In the present study, we found reduced platelet aggregation with AVP in contrast to elevated both PFP and platelet AVP levels after smoking. The finding suggests that endogenously released AVP by smoking after taken up by platelets rapidly desensitizes platelets to exogenously challenged AVP. To clarify whether reduced platelet aggregation with AVP was due to the change in AVP receptor, we performed binding assays before and after smoking. B max of AVP receptors on the washed intact platelets and receptor affinity did not change significantly before and after smoking. Resynthesis and recycling of receptors are also possible mechanisms after the desensitization process as demonstrated in rat smooth muscle cells [26], but recycling to the surface was not observed in human platelet AVP receptors after undergoing internalization and degradation in vitro [27].

The human AVP Vla receptor was cloned and characterized [31]. The precise mechanism of rapid desensitization of AVP Vla receptor was studied in vitro using vascular smooth muscle cells [29], or other cells expressing the cloned receptor [30]. The study using vascular smooth muscle cells showed that hormone receptor occupancy, but not hormone-receptor complex internalization or conformational changes, was incriminated in this AVP homologous desensitization phenomenon. The study also showed that an uncoupling of the hormone-receptor complex and the post-receptor signal transduction mechanisms was important, and that protein kinase $\mathrm{C}$ activation was implicated in AVP-induced desensitization of $\mathrm{Ca}^{2+}$ mobilization in smooth muscle cells.

Homologous rapid desensitization to AVP in human platelets in vitro was also reported [22]. Subsequent addition of AVP to platelets pre-exposed to a quite high concentration $(500 \mathrm{mM})$ of AVP for a short period did not induce $\mathrm{Ca}^{2+}$ mobilization, phosphatidic acid formation or a platelet function response. Our results clearly demonstrate that endogenously released AVP after taken up by platelets desensitize the platelet to AVP in vivo without loss of AVP receptor number or modification of receptor affinity for AVP. 


\section{References}

1) Bichet, D.G. Vasopressin receptors in health and disease. Kidney Int. 49: 1706-1711, 1996.

2) Haslam, R.J. Rosson, M. Aggregation of human blood platelets by vasopressin. Am. J. Physiol. 223: 958-967, 1972.

3 ) Inaba, K., Umeda, Y., Yamane, Y., Urakami, M., Inada, M. Characterization of human platelet vasopres. sin receptor and the relation between vasopressininduced platelet aggregation and vasopressin binding to platelets. Clin. Endocrinol. 29: 377-386, 1988.

4) Thomas, M.E., Osmani, M.H., Scrutton, M.C. Some properties of the human platelet vasopressin receptor. Thromb. Res. 32: 557-566, 1983.

5 ) Thibonnier, M. Roberts, J.M. Characterization of human platelet vasopressin receptors. J. Clin. Invest. 76: 1857-1864, 1985.

6) Launay, J.M., Vittet, D., Vidaud, M., Rondot, A, Mathieu, M. N., Lalau-Keraly, C. Cantau, B., Chevillard, C. V1a-vasopressin specific receptors on human platelets: potentiation by ADP and epinephrine and evidence for homologous down-regulation. Thromb. Res. 45: 323-331, 1987.

7 ) Preibisz, J.J., Sealey, J.E., Laragh, J.H., Cody, R.J., Weksler, B.B. Plasma and platelet vasopres. $\sin$ in essential hypertension and congestive heart failure. Hypertension 5 (Suppl. 1): 129-138, 1983.

$8)$ Nussey, S.S., Ang, V. T.Y., Bevan, D.H., Jenkins, J.S. Human platelet arginine vasopressin. Clin. Endocrinol. (Oxf) 24: 427-433, 1986.

9 ) Bichet, D.G., Arthus, M.F., Barjon, J.N., Lonergan, M., Kortas, C. Human platelet fraction arginine-vasop. ressin: Potential physiological role. J. Clin. Invest. 79: 881-887, 1987.

10) Chesny, C.M., Crofton, J.T., Pifer, D.D., Brooks, D.P., Huch, K.M., Share, L. Subcellular localization of vasopressin-like material in platelets. J. Lab. Clin. Med. 106: 314-318, 1985.

11) Yamamoto, J., Yamane, Y., Umeda, Y., Yoshioka, T., Nakai, M., Ikeda, M. Cardiovascular hemodynamics and vasopressin blockade in DOCA-salt hypertensive rats. Hypertension 6: 397-407, 1984.

12) Feyerabent, C., Russel, M.A.H. Improved gas-chromatographic method and microextraction technique for the measurement of nicotine in biological fluid. J. Pharm. Pharmacol. 31: 73-76, 1979.

13) Born, G.V.R. Aggregation of blood platelets by adenosine diphosphate and its reversal. Nature (London) 194: 927-929, 1962.

14) Burn, J.H., Truelove, L.H., Burn, I. The antidiuretic action of nicotine and of smoking. BMJ. 1: 403-406, 1945.

15) Husain, M.K., Frantz, A.G., Ciarochi, F., Robinson, A.G. Nicotine-stimulated release of neurophysin and vasopressin in humans. J. Clin. Endocrinol. Metab. 41: 1113-1117, 1975.

16) Pomerleau, O.F., Fertig, J.B., Seyler, L.E., Jaffe, J. Neuroendocrine reactivity to nicotine in smokers. Psychopharmacology. 81: 1-67, 1983.

17) Seyler, L.E. Jr., Pomerleau, O.F., Fertig, J.B., Hunt, D., Parker, K. Pituitary hormone response to cigarette smoking. Pharmacol. Biochem. Behav. 24: 159-162, 1986.

18) Rowe, J.W., Kilgore, A., Robertson; G.L. Evidence in man that cigarette smoking induces vasopressin release via an airway-specific mechanism. J. Clin. Endocrinol. Metab. 51: 170-172, 1980.

19) Herning, R.I., Jones, R.I., Benowitz, N.L., Mines, A.H. How a cigarette is smoked determined blood nicotine levels. Clin. Pharmacol. Ther. 33: 84-90, 1983.

20) Goldsmith, S.R., Katz, A., Dodgebrown, D., Crooks, P. Response of plasma arginine vasopressin to nicotine in normal man. Clin. Pharmacol. Ther. 44: 478-481, 1988.

21) Thibonnier, M., Goraya, T., Berti-Mattera, L. $\mathrm{G}$ protein coupling of human platelet $\mathrm{V} 1$ vascular vasopressin receptors. Am. J. Physiol. 264: C1336-C1344, 1993.

22) Pollock, W.K., MacIntyre, D.E. Desensitization and antagonism of vasopressin-induced phosphoinositide metabolism and elevation of cytosolic free calcium concentration in human platelet. Biochem. J. 234: 67-73, 1986.

23) Hawkins, R.I. Smoking, platelets and thrombosis. Nature (London). 236: 450-452, 1972.

24) Levine, P.H. An acute effect of cigarette smoking 
on platelet function: A possible link between smoking and arterial thrombosis. Circulation 48: 619-623, 1973.

25) Saba, S.R., Mason, R.G. Some effects of nicotine on platelets. Thromb. Res. 7: 819-824, 1975.

26) Briner, VA., Williams, B., Tsai, P., Shreier, R.W. Demonstration of processing and recycling of biologically active $\mathrm{V} 1$ receptors in vascular smooth muscle. Proc. Nat1. Acad. Sci. 89: 2854-2858, 1992.

27) Thibonnier, M. Internalization, degradation, and down regulation of human platelet vasopressin receptors. Clin. Pharmacol. Ther. 43: 163, 1988.

28) Erne, P., Pletscher, A., Raine, A.E.G., Rogg, H., Nussberger, J., Buhler, F.R. Smoking-induced increases in plasma vasopressin and reduced platelet hormone sensitivity. J. Cardiovasc. Pharmacol. 8 (Suppl. 7): S1 -S22, 1986.

29) Caramelo, C., Tsai, P., Okada, K., Briner, VA., Schrier, RW. Mechanisms of rapid desensitization to arginine vasopressin in vascular smooth muscle cells. Am. J. Physiol. 260: F46-F52, 1991.

30) Ancellin, N., Preisser, L., Corman, B., Morel, A. Role of protein kinase $C$ and Carboxyl-terminal region in acute desensitization of vasopressin $\mathrm{V} 1 \mathrm{a}$ receptor. FEBS Letters. 413: 323-326, 1997.

31) Thibonnier, M., Auzan, C., Madhun, Z., Wilkins, P., Berti-Mattera, L., Clauser, E. Molecular cloning, sequencing, and functional expression of a cDNA encoding the human V1a vasopressin receptor. J. Biol. Chem. 269: 3304-3310, 1994. 